\title{
3 \\ The connectivity of the Greater Mekong Subregion: A view from the sky
}

\author{
Wichsinee Wibulpolprasert, Winit Theanvanichpant \\ and Somkiat Tangkitvanich1
}

Countries succeed when they have a magnetic quality and an openness to the world around them: when they invest more in bridges than walls.

— Tom Fletcher (2016: 18)

\section{Introduction}

Transport infrastructure is an important element for both local and crossborder economic development. In the past 20 years, the Greater Mekong Subregion (GMS) has seen remarkable growth in the amount of transport infrastructure that connects countries in the region along numerous economic corridors, as shown in Figure 3.1.

1 We are grateful to Panu Nuangjumnong and Jirawit Wongchan-Uma from Geo-Informatics and Space Technology Development for their assistance in digitising and interpreting the satellite data. We also would like to thank Dr Watcharas Leelawath and Dr Souknilanh Keola for their helpful comments. 


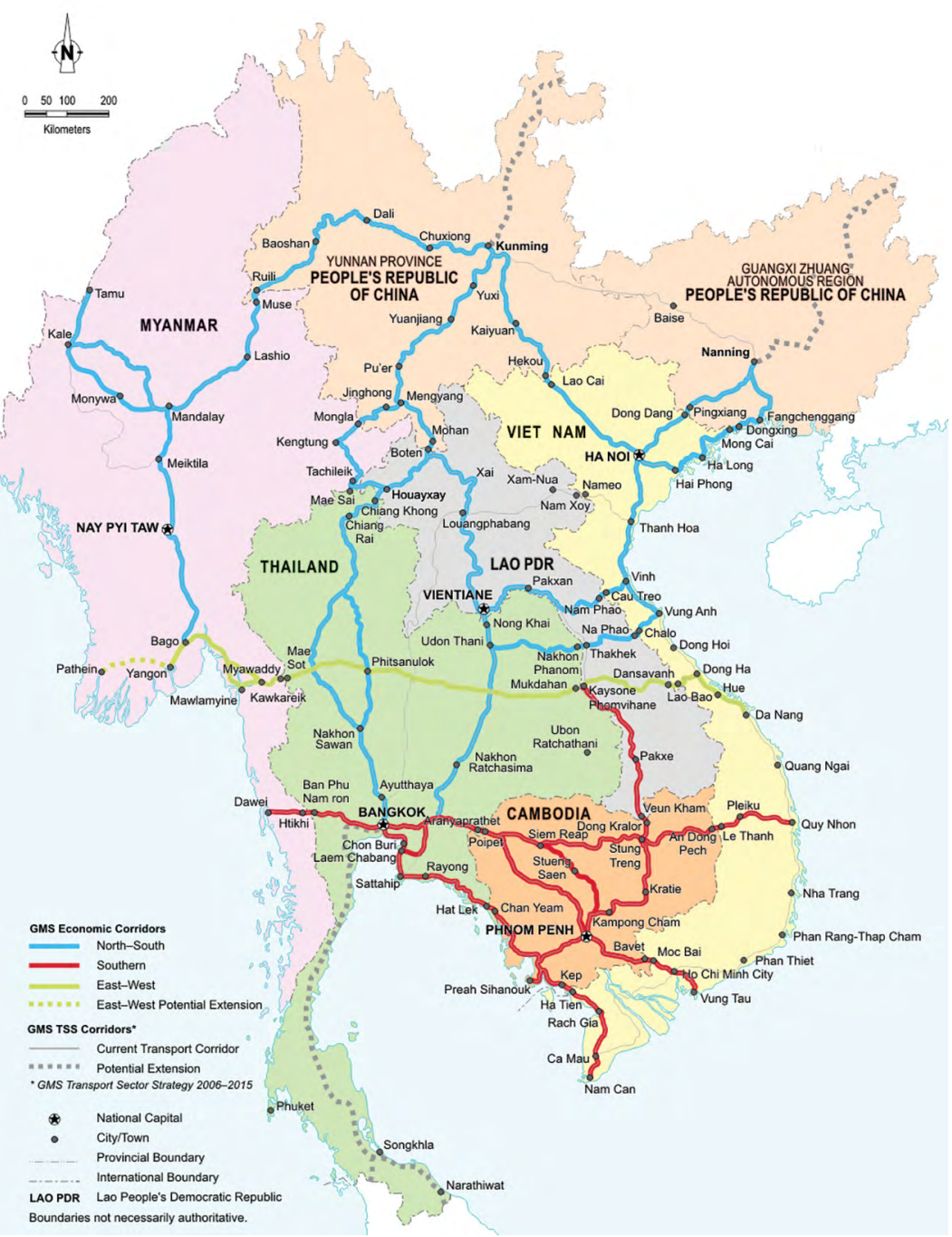

Figure 3.1 GMS economic corridors

Source: www.greatermekong.org.

One prominent example of this connectivity is the series of ThailandLaos friendship bridges across the Mekong River (see Table 3.1). The first friendship bridge opened in April 1994 and connects Vientiane prefecture in Lao People's Democratic Republic (Lao PDR) to Thailand's Nong Khai Province. The second bridge opened in January 2007, connecting Suvannakhet (Lao PDR) to Mukdahan (Thailand). The third 
bridge connects Nakhon Phanom (Thailand) to Thakhek, Khammouan (Lao PDR), and opened in November 2011. The most recent friendship bridge was completed in December 2013, connecting Chiang Khong (Thailand) to Ban Houayxay (Lao PDR).

Table 3.1 Thailand-Laos friendship bridges

\begin{tabular}{|l|l|l|l|l|}
\hline Bridge & Opening date & Thailand & Laos & Funded by \\
\hline First & April 1994 & Nongkhai & Vientiane & Australian Government \\
\hline Second & December 2006 & Mukdahan & Savannakhet & Japanese loan \\
\hline Third & November 2011 & Nakhon Phanom & Khammouan & Thai Government \\
\hline Fourth & December 2013 & Chiang Rai & Ban Houayxay & $\begin{array}{l}\text { Thai, Lao and Chinese } \\
\text { governments }\end{array}$ \\
\hline
\end{tabular}

Sources: Fernquest (2011); Wikipedia; Fujimura (2017).

Connective structures such as cross-border bridges allow regional trade to prosper by significantly reducing transportation times and costs. While the direct benefit of reduced transportation costs/times from enhanced connectivity is usually apparent and easily measurable, the indirect benefits that spill over to local communities are much harder to measure due to the lack of microlevel data.

Given the announcement of additional friendship bridge investments, understanding the interactions between the connective infrastructure investments, local economic activities and urbanisation can be informative from a cost-benefit standpoint as well as for urban planning purposes.

To our knowledge, existing studies that evaluate microlevel impacts of infrastructure in the GMS are rare due to the unavailability of finegrained urbanisation and economic data. Most are the feasibility studies conducted by investors prior to commissioning the construction project (MOT 2008), ex-ante studies (Warr et al. 2009) or post-evaluation descriptive studies that focus on the direct trade benefits (Fujimura 2017).

For an ex-ante study, Warr et al. (2009) use a general equilibrium model to estimate the effects of the second Mekong River bridge. Their results suggest that, in the short run, transport cost reductions would produce a modest increase in interregional trade volumes in both directions and a small increase in real consumption in Thailand and Lao PDR. Over a longer period, the economic benefits to both regions would be much 
larger, as capital and labour become more mobile. They do not confirm the belief that the benefits of cross-border infrastructure projects occur only, or overwhelmingly, in the richer region.

The most comprehensive post-evaluation study was conducted by Fujimura (2017), which quantified the cost-benefit ratios along selected segments of the GMS economic corridors as well as the economic impacts at the country or subregional level. Despite finding a net positive economic impact from infrastructure in the GMS as a whole, the author admitted that incomplete data could compromise the robustness of the results.

The various remote sensing data that became available recently, along with the development of image classification techniques, have great potential to fill this gap and allow researchers to conduct retrospective microlevel studies of infrastructure investment that have not been possible before. For example, a study by Vernon Henderson et al. (2012) famously demonstrates that local economic activity can be estimated from satellite images of observed night light. Several other existing studies have developed classification techniques to translate raw satellite images into meaningful pixel-based identification of built-up areas and different types of land use (Goldblatt et al. 2016, 2018).

This study sets out to answer two questions that characterise the relationship between connective infrastructure, local industrialisation and local urbanisation. The first is whether connective infrastructure is a necessary condition for industrialisation, or is it industrialisation/ trade that necessitates the construction of bridges (the bridges are just enhancers)? Second, are there any indirect benefits (spillovers) from either the bridge construction or the industrialisation on the local economy?

We will focus our analysis on the impacts of the construction of the second (2007) and third (2009) Thailand-Laos friendship bridges as the time before and since their opening dates allow us long enough observation periods. Our analysis strategy follows three steps. First, we construct a measurement of urbanisation over time using publicly available data from various sources. We then characterise the interaction between connective infrastructure (the friendship bridges), industrialisation and patterns of local urbanisation. Last, we synthesise policy implications and lessons learned for the future development of connective infrastructure in the GMS. 


\section{Literature review}

While this chapter will focus on the relationship between cross-border infrastructure, local industrialisation and local urbanisation, this section will review previous research more broadly to gain insights into the impacts of transport infrastructure on trade and urbanisation.

There are numerous studies of the impacts of transport infrastructure on trade, all of which seem to confirm that the presence of transport infrastructure (road networks, airports, railways and ports) has resulted in increased trade flows (for example, Ismail and Mahyideen 2015; Celbis et al. 2013). In the context of the GMS economies, Fujimura and Edmonds (2006) find that cross-border and domestic transport infrastructure together can reduce trade costs and lead directly to increased trade and investment.

However, there are far fewer studies related to the impacts of transport infrastructure on urbanisation patterns. Most empirical works are undertaken in the context of developed countries. A typical finding is that improved transport infrastructure leads to agglomeration economies of increased access to markets, innovation spillovers and a greater labour pool (for example, Duranton and Puga 2004; World Bank 2009). Most existing works also focus on intracity roads and metro lines, rather than intercity transport infrastructure. Studies of the impacts of cross-border infrastructure such as international bridges are even harder to find, especially in the context of developing countries.

Baum-Snow et al. (2012) find the configurations of urban railroads and highways have influenced urban forms in Chinese cities since 1990. In particular, each radial highway displaces about 4 per cent of the central city's population to surrounding regions and ring roads displace an additional 20 per cent or so, with stronger effects in the richer coastal and central regions. Each radial railroad reduces central-city industrial gross domestic product (GDP) by about 20 per cent, with ring roads displacing an additional 50 per cent.

More recent empirical studies are related to the impact of high-speed rail networks in China and Japan. In the case of China, Ke et al. (2017) construct hypothetical counterfactuals for per capita real GDP of cities along the high-speed rail network in the absence of their respective high-speed rail projects. They find that the gains from high-speed rail are heterogeneous with regard to location, route and region. Cities with 
positive effects are concentrated in the eastern coastal regions of China and in core urban agglomeration regions that allow them to become transportation hubs. In general, the gain for local economies is greater for cities that are more industrialised, with greater ability for the service sector to absorb labour and better supporting infrastructure.

Using the least-cost spanning tree to address the nonrandom route selection issue, Yu et al. (2019) find that high-speed railway connections in China have led to a reduction in GDP per capita for connected peripheral prefectures. They also find that the reduction of GDP per capita is driven by significant contractions in capital inputs, industrial outputs and skilled labour outflows.

In the case of Japan, $\mathrm{Li}$ and $\mathrm{Xu}$ (2018) show that high-speed railroads can either polarise or diffuse economic geography based on the sector and distance between cities. In other words, economic activity could agglomerate from distant to core areas or disperse from the core to the periphery at the same time. To support their findings, they cite empirical evidence from the 1982 introduction of two major high-speed railways in Japan, which halved intercity transit times. They find that noncore areas lost 3-6 per cent of their population; service sector employment declined by 7 per cent, whereas manufacturing employment increased by 21 per cent. Municipalities within approximately 150 kilometres of Tokyo expanded, while the more distant ones contracted.

Overall, previous research finds that transport infrastructure tends to increase economic activity, trade and output. However, intercity transport links often produce uneven results in economic activity and urbanisation patterns among larger cities (hubs) and smaller ones (spokes or peripheries).

\section{Background to the friendship bridges}

\section{The second Mekong friendship bridge}

The second Thailand-Laos Mekong Friendship Bridge was completed in November 2006. It connects Mukdahan and Savannakhet and was designed to be a part of the GMS's East-West Economic Corridor (EWEC), which stretches from Yangon, Myanmar, in the west to Danang, Vietnam, in the east. 
The second bridge construction project, funded by a Japanese Government official development assistance (ODA) loan, aimed to promote regional economic development, logistics and trade through the corridor. Prior to the bridge's opening, a ferry service was the only transport option to cross the river. Transporting goods from Bangkok to Hanoi via ship took from one and a half to two weeks. Transport overland via the second friendship bridge reduced the time to three days (JIBTV 2014).

Apart from promoting regional connectivity, the second friendship bridge was partially built to support Japanese industries that operate in the region. The first special economic zone (SEZ) in Laos, the Savan-Seno SEZ, was completed in Savannakhet in 2003. Some Japanese factories consider the Savan-Seno SEZ a perfect location, for several reasons. First, goods can be transported overland to either Da Nang port in Vietnam (to be shipped to East Asian countries) or Laem Chabang port in Thailand. Second, labour and electricity costs are much cheaper in Laos than in Thailand (JIBTV 2014).

With these considerations in mind, the Japanese Government, via the Japan International Cooperation Agency (JICA), helped complete an improvement project for National Road No. 9 that connects Savannakhet in Laos to Vietnam. This, along with the construction of the second friendship bridge connecting Thailand to Savannakhet, naturally made the landlocked Laos a more attractive manufacturing and distribution base, which has attracted many Japanese firms to establish their factories there (JICA 2017).

The industrial and connective infrastructure development of the SavanSeno SEZ and the second friendship bridge is considered a perfect example of the 'Thailand-plus-one business model' for Japanese firms. The model proposes that Japanese companies that operate industrial clusters in Thailand can shift some of their labour-intensive activities to SEZs in the CLM countries (Cambodia, Laos and Myanmar) near the Thai border. Such a strategy will enhance the companies' supply chain competitiveness via the lower labour costs in the CLM countries while maintaining access to the strengthened transportation infrastructure in Thailand (Oizumi 2013).

With the above context in mind, we hypothesise the relationship between connectivity, industrialisation and urbanisation for the second friendship bridge as follows: industrialisation (the establishment of the SEZ) drives local urbanisation and the demand for connective infrastructure. 


\section{The third Mekong friendship bridge}

The third friendship bridge was commissioned in a vastly different context than the second bridge. First, it was financed by Thailand's government with the objective of strengthening regional connectivity in general. The third bridge is part of Asian Highway Route AH15, connecting Thailand's Udon Thani Province to Vinh in Vietnam. It also gives closer trade access to southern China. According to the feasibility study, the third bridge shortened ground shipping from Thailand to central Vietnam by 100 kilometres, saving approximately two hours of driving compared with crossing the second bridge (MOT 2008). Second, there was no industrial base or SEZ in the area before the bridge's construction. Instead, the Government of Laos decided to establish the Thakhek SEZ right across the Mekong River from Nakhon Phanom after the bridge was finished, with the aim of capturing the spillover benefits from the improved connectivity (Royal Thai Consulate-General 2019).

With these differences in mind, we hypothesise the relationship between connectivity, industrialisation and urbanisation for the third friendship bridge as follows: connectivity (from the bridge) drives industrialisation and (perhaps) urbanisation.

\section{Data and methodology}

\section{Macrolevel data}

Table 3.2 summarises the high-level indicators of the local economy and urbanisation in Thailand's provinces.

Table 3.2 High-level indicators for local urbanisation

\begin{tabular}{|l|l|l|l|}
\hline Indicator & Description & Data period & Data source \\
\hline $\begin{array}{l}\text { Cross-border } \\
\text { trade value }\end{array}$ & $\begin{array}{l}\text { Export and import value of } \\
\text { trade along the Mukdahan- } \\
\text { Savannakhet and Nakhon } \\
\text { Phanom-Kammouan borders }\end{array}$ & 2003-16 & $\begin{array}{l}\text { Bank of Thailand } \\
\text { (Bank of Thailand } \\
\text { n.d.) }\end{array}$ \\
\hline $\begin{array}{l}\text { Cross-border } \\
\text { traffic volume }\end{array}$ & $\begin{array}{l}\text { Number of inbound/outbound } \\
\text { passenger vehicles, trucks } \\
\text { and passengers passing } \\
\text { through the Mukdahan- } \\
\text { Savannakhet and Nakhon } \\
\text { Phanom-Kammouan } \\
\text { immigration checkpoints }\end{array}$ & 2008-18 & $\begin{array}{l}\text { Mukdahan and } \\
\text { Nakhon Phanom } \\
\text { immigration offices } \\
\text { (Mukdahan Customs } \\
\text { House 2019; Nakhon } \\
\text { Phanom Immigration } \\
\text { Office 2012) }\end{array}$ \\
\hline
\end{tabular}




\begin{tabular}{|l|l|l|l|}
\hline Indicator & Description & Data period & Data source \\
\hline $\begin{array}{l}\text { Gross provincial } \\
\text { product }\end{array}$ & $\begin{array}{l}\text { Province-level measure of } \\
\text { value added }\end{array}$ & $2002-18$ & $\begin{array}{l}\text { Office of the National } \\
\text { Economic and Social } \\
\text { Development Council } \\
\text { (NESDC n.d.) }\end{array}$ \\
\hline $\begin{array}{l}\text { Yearly built-up } \\
\text { area expansion }\end{array}$ & $\begin{array}{l}\text { New built-up area in square } \\
\text { kilometres that appears yearly, } \\
\text { as identified from satellite } \\
\text { imagery }\end{array}$ & $2001-18$ & $\begin{array}{l}\text { Landsat 5,7, } 8 \\
\text { (details below) } \\
\text { (USGS n.d.) }\end{array}$ \\
\hline
\end{tabular}

\section{Satellite imagery data}

Our satellite imagery data for the study area come from Landsat 5, 7 and 8. The Landsat satellites take pictures of the Earth's surface and record reflected energy in various wavelengths of the electromagnetic spectrum ('bands') (NASA n.d.). Each pixel represents a gridded area of approximately 30 by 30 metres (that is, a resolution of 30 metres).

\section{Table 3.3 Examples of the various bands in Landsat 5 and 8}

\begin{tabular}{|l|l|l|l|l|}
\hline $\begin{array}{l}\text { Band } \\
\text { no. }\end{array}$ & Band name & Wavelength $(\boldsymbol{\mu m})$ & Resolution $\mathbf{( m )}$ & Band applications \\
\hline 1 & Visible Blue & $0.45-0.52$ & 30 & $\begin{array}{l}\text { Bathymetric mapping, } \\
\text { distinguishing soil } \\
\text { from vegetation and } \\
\text { deciduous from } \\
\text { coniferous vegetation }\end{array}$ \\
\hline 2 & $\begin{array}{l}\text { Visible } \\
\text { Green }\end{array}$ & $0.52-0.60$ & 30 & $\begin{array}{l}\text { Emphasises peak } \\
\text { vegetation, which is } \\
\text { useful for assessing } \\
\text { plant vigour }\end{array}$ \\
\hline 3 & Visible Red & $0.63-0.69$ & 30 & $\begin{array}{l}\text { Discriminates vegetation } \\
\text { slopes }\end{array}$ \\
\hline 4 & NIR & $0.76-0.90$ & 30 & $\begin{array}{l}\text { Emphasises biomass } \\
\text { content and shorelines }\end{array}$ \\
\hline 5 & SWIR 1 & $1.55-1.75$ & 30 & $\begin{array}{l}\text { Discriminates moisture } \\
\text { content of soil and } \\
\text { vegetation; penetrates } \\
\text { thin clouds }\end{array}$ \\
\hline 6 & Thermal & $10.40-12.50$ & 120 & $\begin{array}{l}\text { Thermal mapping and } \\
\text { estimated soil moisture }\end{array}$ \\
\hline 7 & SWIR 2 & $2.08-2.35$ & 30 & $\begin{array}{l}\text { Hydrothermally altered } \\
\text { rocks associated with } \\
\text { mineral deposits }\end{array}$ \\
\hline
\end{tabular}

Source: EOSDA (n.d.). 


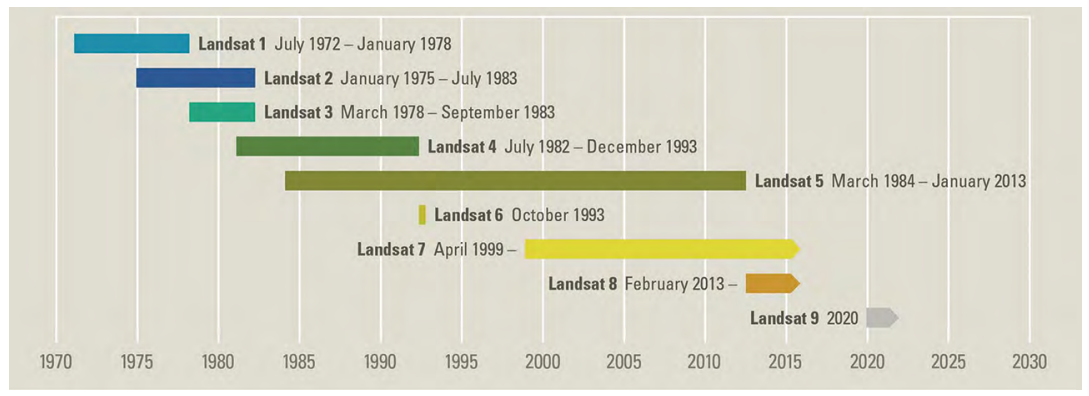

Figure 3.2 Landsat mission schedule

Source: USGS (n.d.).

Since different satellites have different mission periods (Figure 3.2), we had to combine the snapshot imagery data from three different satellites-Landsat 5, 7 and 8-to cover our entire study period, from 2000 to 2020 (De Riggi 2017).

We acquired the resulting dataset that records various bands of wavelength in the target area from the EarthExplorer website of the United States Geological Survey (USGS n.d.). Note that even though the images of the same location are taken every 16 days, we screened only for the best yearly snapshot with the lowest cloud cover. Table 3.4 summarises our yearly data source and the snapshot time frame.

Table 3.4 Final satellite imagery data source

\begin{tabular}{|l|l|l|l|}
\hline \multirow{2}{*}{ Year } & \multicolumn{2}{|l|}{ Data date } & \multirow{2}{*}{ Satellite } \\
\cline { 2 - 3 } & Mukdahan/Savannakhet & Nakhon Phanom/Khammouan & \\
\hline 2000 & 4 November 2000 & 4 November 2000 & Landsat-7 \\
\hline 2001 & 23 November 2001 & 23 November 2001 & Landsat-7 \\
\hline 2002 & 10 November 2002 & 10 November 2002 & Landsat-7 \\
\hline 2003 & 21 November 2003 & 21 November 2003 & Landsat-5 \\
\hline 2004 & 22 October 2004 & 22 October 2004 & Landsat-5 \\
\hline 2005 & 10 November 2005 & 10 November 2005 & Landsat-5 \\
\hline 2006 & 12 October 2006 & 12 October 2006 & Landsat-5 \\
\hline 2007 & 8 November 2007 & 8 November 2007 & Landsat-7 \\
\hline 2008 & 4 December 2008 & 4 December 2008 & Landsat-5 \\
\hline 2009 & 4 October 2009 & 4 October 2009 & Landsat-5 \\
\hline 2010 & 20 October 2010 & 20 October 2010 & Landsat-5 \\
\hline 2011 & 6 July 2011 & 6 July 2011 & Landsat-5 \\
\hline 2012 & 20 October 2012 & 20 October 2012 & Landsat-7 \\
\hline
\end{tabular}




\begin{tabular}{|l|l|l|l|}
\hline \multirow{2}{*}{ Year } & \multicolumn{2}{|l|}{ Data date } & \multirow{2}{*}{ Satellite } \\
\cline { 2 - 4 } & Mukdahan/Savannakhet & Nakhon Phanom/Khammouan & \\
\hline 2013 & 7 October 2013 & 7 October 2013 & Landsat-7 \\
\hline 2014 & 2 October 2014 & 2 October 2014 & Landsat-8 \\
\hline 2015 & 1 July 2015 & 1 July 2015 & Landsat-8 \\
\hline 2016 & 14 June 2016 & 14 June 2016 & Landsat-8 \\
\hline 2017 & 26 October 2017 & 26 October 2017 & Landsat-8 \\
\hline 2018 & 13 October 2018 & 13 October 2018 & Landsat-8 \\
\hline
\end{tabular}

Last, the data preparation and classification steps were performed on ENVI and ArcGIS software. Figure 3.3 summarises the data-processing steps.

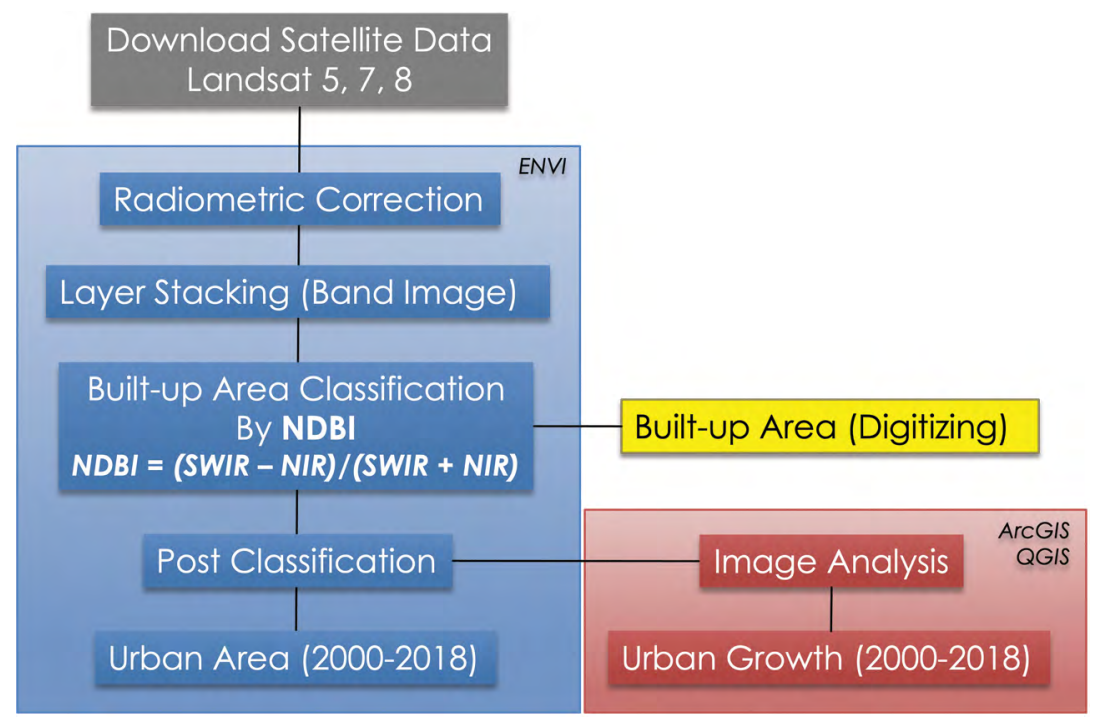

Figure 3.3 Data-processing steps

Source: Geo-Informatics and Space Technology Development team.

\section{Built-up area classification}

The next step in data processing is to translate the raw wavelength data into meaningful measures of urbanisation. We make use of the widely used Normalized Difference Built-Up Index (NDBI) to classify image pixels as built-up and non-built-up areas. The NDBI utilises the properties of built-up areas and bare soil, which reflect more shortwave infrared (SWIR) than near-infrared (NIR) waves, while green vegetation generally reflects more NIR than SWIR. 
The NDBI is calculated using the formula:

$$
N D B I=\frac{S W I R-N I R}{S W I R+N I R}
$$

The index value ranges from -1 to 1 and can be interpreted as follows:

- NDBI $>0$ and close to 1 indicates a built-up area.

- NDBI close to 0 indicates a vegetated area.

- $\mathrm{NDBI}<0$ and close to -1 indicates a water body.

This study uses an NDBI cut-off value of 0.65 to classify pixels as built-up area. Note that we finetune the cut-off values for different data years to achieve the highest classification accuracy.

After an initial classification using the NDBI, we are still left with many false-positive built-up areas. This is because the NDBI alone cannot distinguish real built-up areas from barren land with bare soil. Thus, we refine our classification results with two additional steps. First, we compare the initial classified data against verified land use data and highresolution satellite imagery from the most recent year (2018). The logic is simple: the verified land use data and high-resolution images constitute our 'ground truth' for the real built-up area boundary, thus any built-up pixels classified initially by the NDBI that fall outside this boundary in 2018 are false positives and are excluded from our data layer in all years. Next, we perform a final visual inspection by comparing the resulting classified built-up area with the raw satellite image year by year. We then manually remove from our dataset the classified built-up areas that do not look like real built-up areas.

\section{Strengths and limitations of using satellite imagery data}

Using the satellite imagery (Landsat) data to track urbanisation progress has several strengths. First, it is publicly available online. This makes it affordable and accessible for anyone. Second, the data span a long period. This allows researchers to study land use changes before the administrative data became available. Third, the imagery data are truthful in the sense that they are recorded by the camera's sensors and are not easily manipulated. 
Despite these many advantages, there are several limitations that readers should beware of when interpreting the results in this chapter. First, the Landsat data's resolution of 30 metres is considered relatively low. This property naturally lends itself to a simple classification method such as the NDBI rather than a more sophisticated/accurate classification method. Second, while the NDBI is easy to calculate and interpret, it is not highly accurate and requires additional post-classification refinements, as mentioned above. Third, even when the NDBI can classify built-up pixels correctly, it cannot distinguish between different types of built-up areas. This limitation means that, without additional information, researchers will not be able to assess the quality of urbanisation, as both highly developed and less-developed areas will be classified as built-up.

In addition to the satellite imagery data, we have explored the usability of night-time light imagery data. The main night-time light data that cover our period of interest are the OLS-DMSP night-time light series provided by the US National Centers for Environmental Information (NCEI n.d.). Unfortunately, this dataset has several limitations. First, and most importantly, the different satellites used to collect data for this series have different (unknown) baseline calibration values, which means the night-time light index is not comparable across years. This limitation is particularly noticeable when the study area is small. Second, the low resolution of the night-time light data (1 kilometre) prevent detailed geospatial analysis, which is crucial when our study areas are small.

\section{Results and discussion}

This section discusses the observed relationships between the construction of the friendship bridges, urbanisation and trade activity. Recall that our focus areas are Mukdahan (Thailand) and Savannakhet (Laos) for the second friendship bridge and Nakhon Phanom (Thailand) and Thakhek (Laos) for the third friendship bridge.

\section{Macrolevel changes post bridge construction}

We first investigate the province-level changes in different indicators of urbanisation, starting with cross-border trade volumes. Figure 3.4 shows the yearly export and import trade values (in million Thai baht, or THB) across the Mukdahan-Nakhon Phanom border. Two interesting 
observations stand out. First, border trade value is dominated by exports to rather than imports from Laos. Closer inspection reveals that the top export products across Mukdahan's border are computing chips and electronic circuits, while the top import products are pure copper and appliance components. On the other hand, the top export products from Nakhon Phanom are computer memory units and fruit, while the top import products into Nakhon Phanom are mainly electronic devices, memory hard disks and computers. Second, both the export and the import trade values increased exponentially shortly after the opening of the two friendship bridges. These two observations clearly indicate the direct benefit of the bridges on trade facilitation.
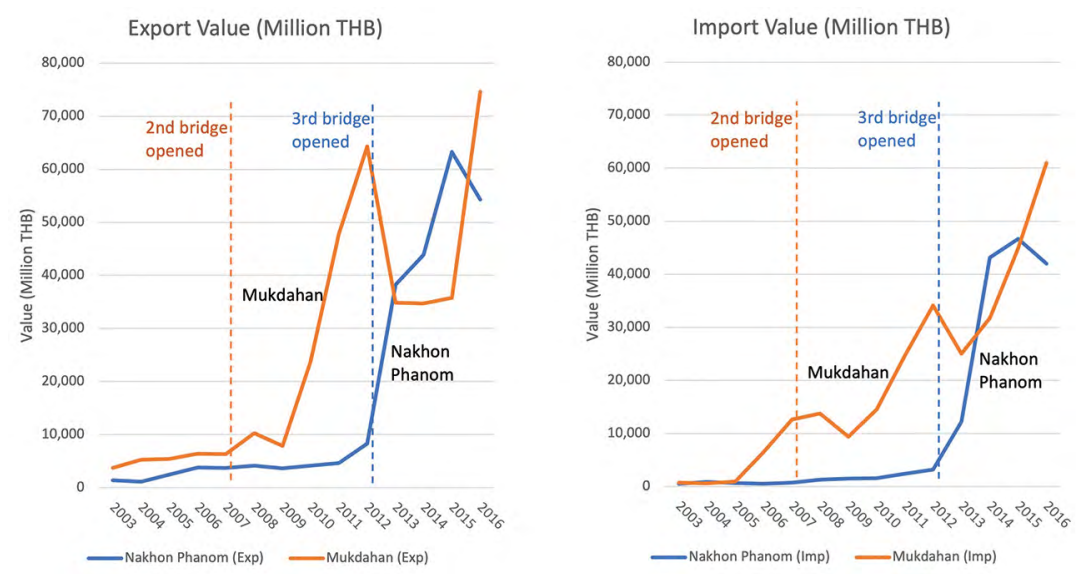

Figure 3.4 Changes in border export and import values

Source: Authors' creation.

Next, we look at the combined (inbound and outbound) cross-border traffic volume over time, in Figure 3.5. Unfortunately, no data are available before 2008, making it impossible to spot whether there was any abrupt change in traffic volume after the second bridge opened. However, if we assume that the change in traffic volume follows a pattern similar to that of the change in trade value, we expect to see the traffic volume for the second bridge spike after 2009. Unlike the change in trade value, however, the cross-border traffic volume seems to increase only gradually over time. The observed exponential growth in trade value along with a gradual increase in traffic volume (especially truck traffic) imply a significant increase in the proportion of high-value products among the goods traded or a significant improvement in truck capacity utilisation, or both. 


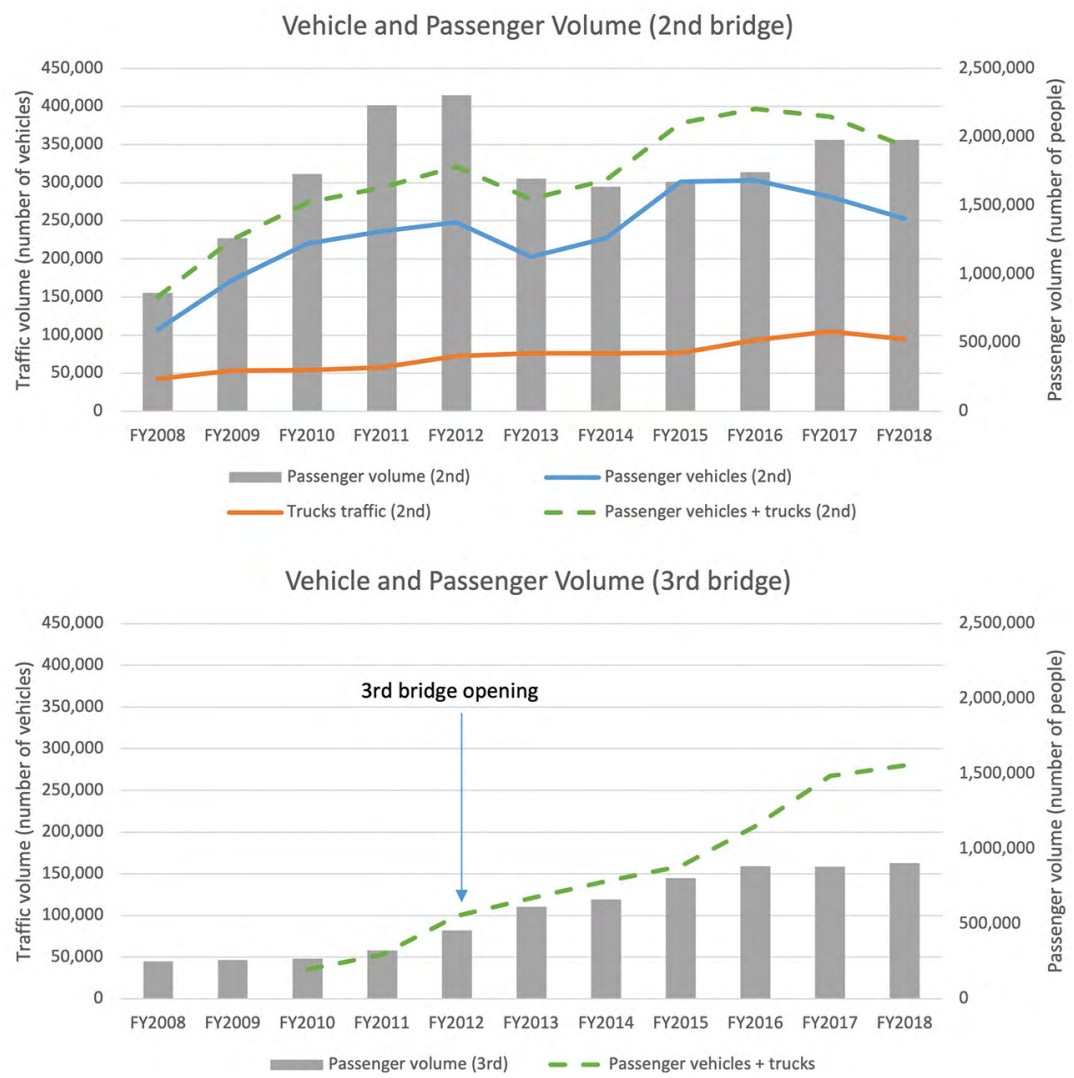

Figure 3.5 Cross-border traffic volume

Source: Authors' creation.

Last, we inspect the year-on-year change in the expansion of built-up areas and the gross provincial product (GPP) of the two Thai border provinces, in Figures 3.7 and 3.8. We notice a rapid expansion of built-up areas in the early 2000s, which gradually slows over time. This slowdown is mainly a result of the fact that there was only a very small built-up area in all the regions being studied in the base year, 2002. Therefore, a small expansion in built-up area translates to large year-on-year growth. First, similar to traffic volume, the built-up area expansion or increase in GPP does not seem to respond to the opening of the two bridges in any significant way. 


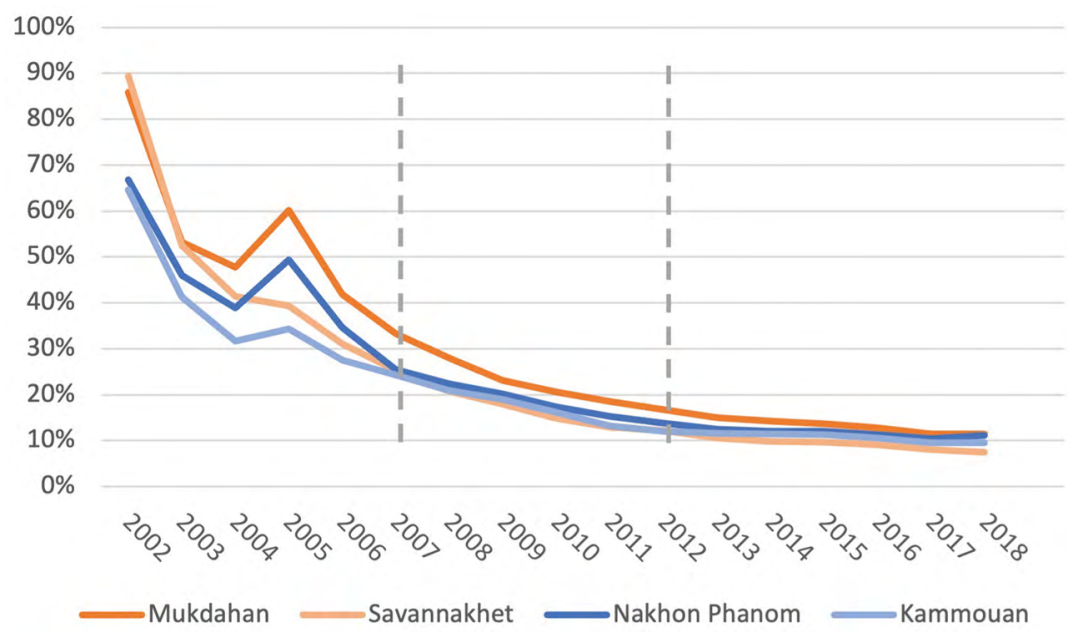

Figure 3.6 Year-on-year change in built-up area expansion

Source: Authors' creation.

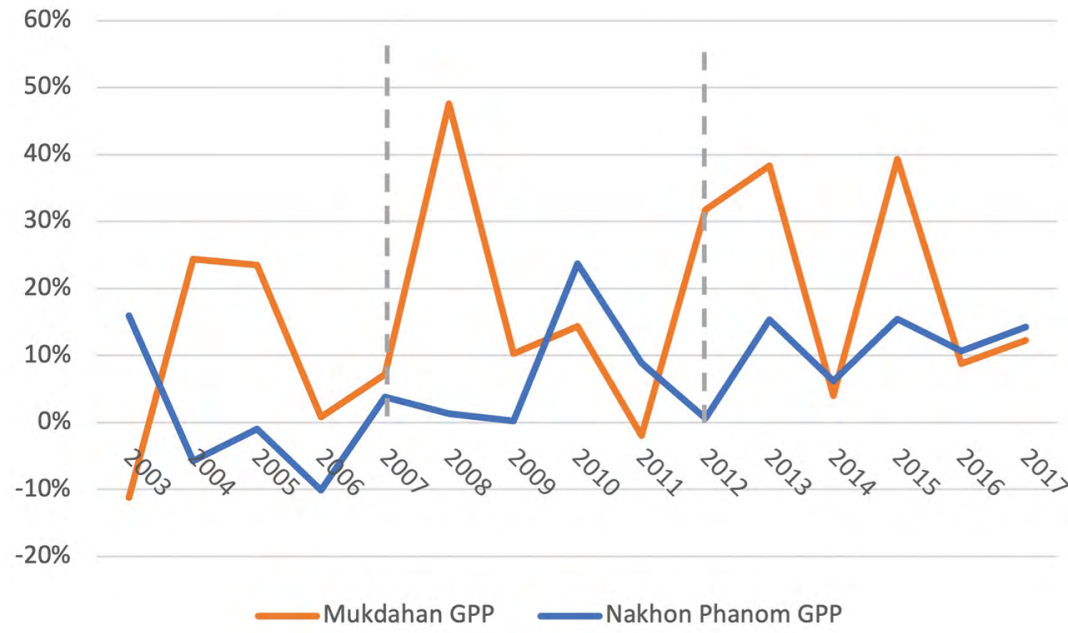

Figure 3.7 Year-on-year change in GPP

Source: Authors' creation.

Together, all the province-level data indicate that, besides providing the obvious direct trade benefits, the friendship bridges seem to have had limited impact on local urbanisation. 


\section{Built-up area growth pattern}

We next turn our attention to the pattern of built-up area expansion around the two friendship bridges. Figure 3.8 shows this expansion in 2000, 2005, 2009 and 2015. Each dot represents a new built-up area created in each year. The orange or red colour indicates locations with a high density of new built-up areas ('built-up hotspots'). We can see the intense built-up hotspots in Savannakhet that occurred near the city's core in 2005, which corresponded with the opening of the Savan-Seno SEZ in 2003. New built-up hotspots in Mukdahan, on the other hand, are less intense and are scattered along the existing highways and city core. By comparing the built-up hotspot map from 2005 (before the bridge's opening) with that from 2009 (after the bridge's opening), we can see that the second friendship bridge did not seem to change the pattern of builtup area expansion in a profound way.

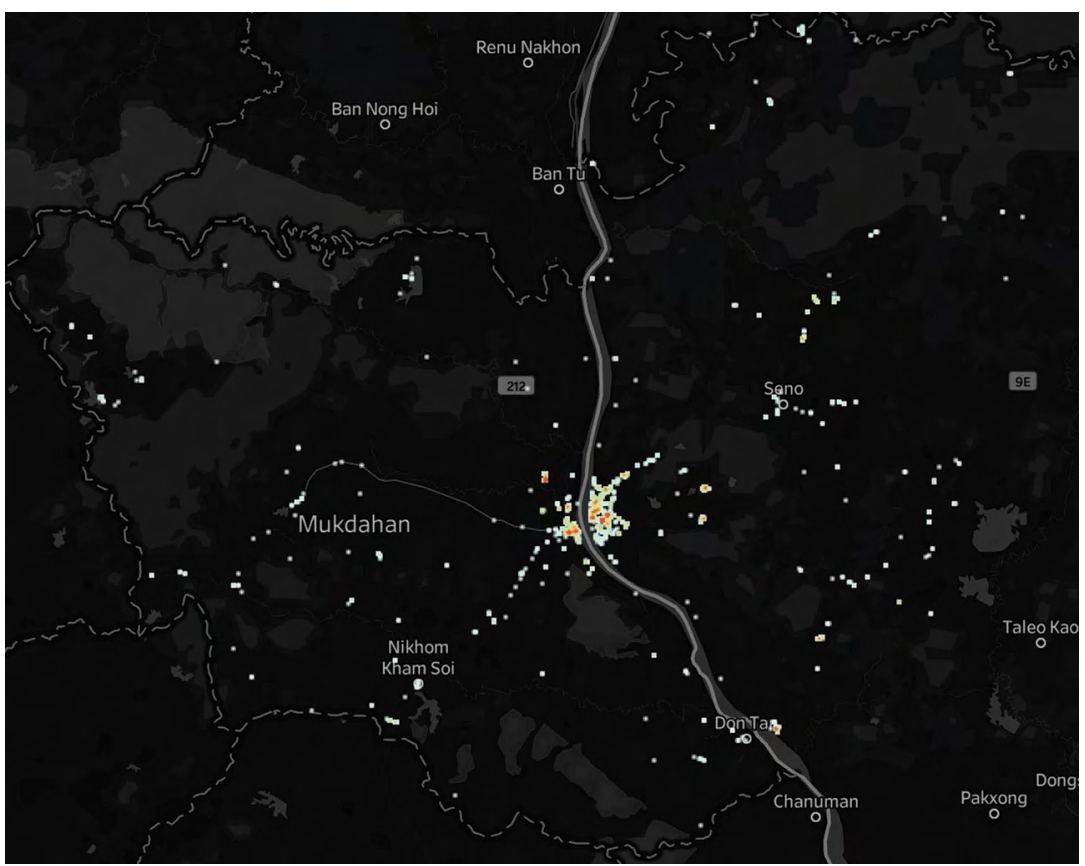

Figure 3.8a Location of newly created built-up areas in 2000 (second bridge)

Source: Authors' creation. 


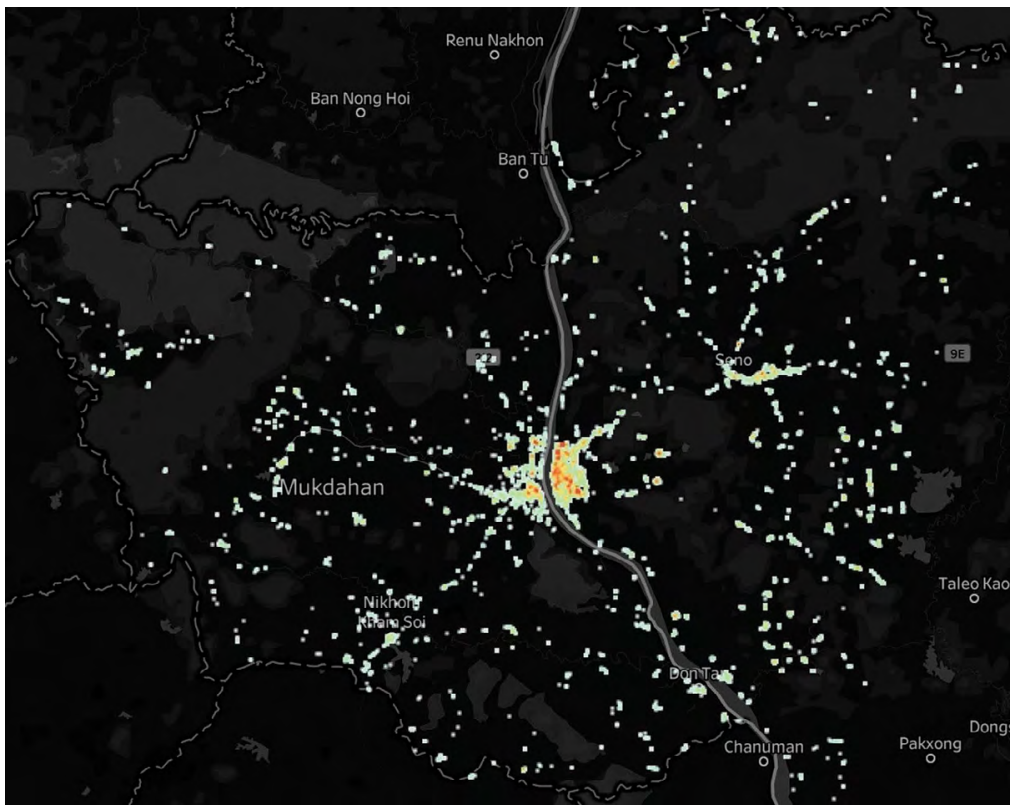

Figure 3.8b Location of newly created built-up areas in 2004 (second bridge)

Source: Authors' creation.

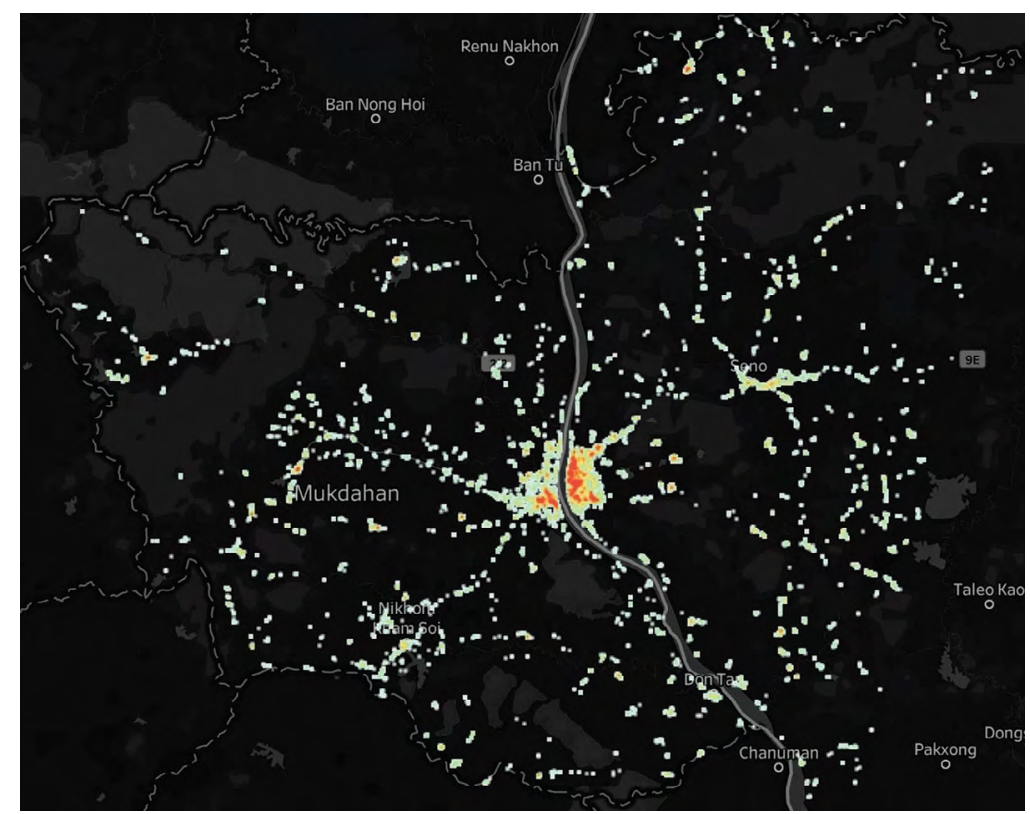

Figure 3.8c Location of newly created built-up areas in 2005 (second bridge) 


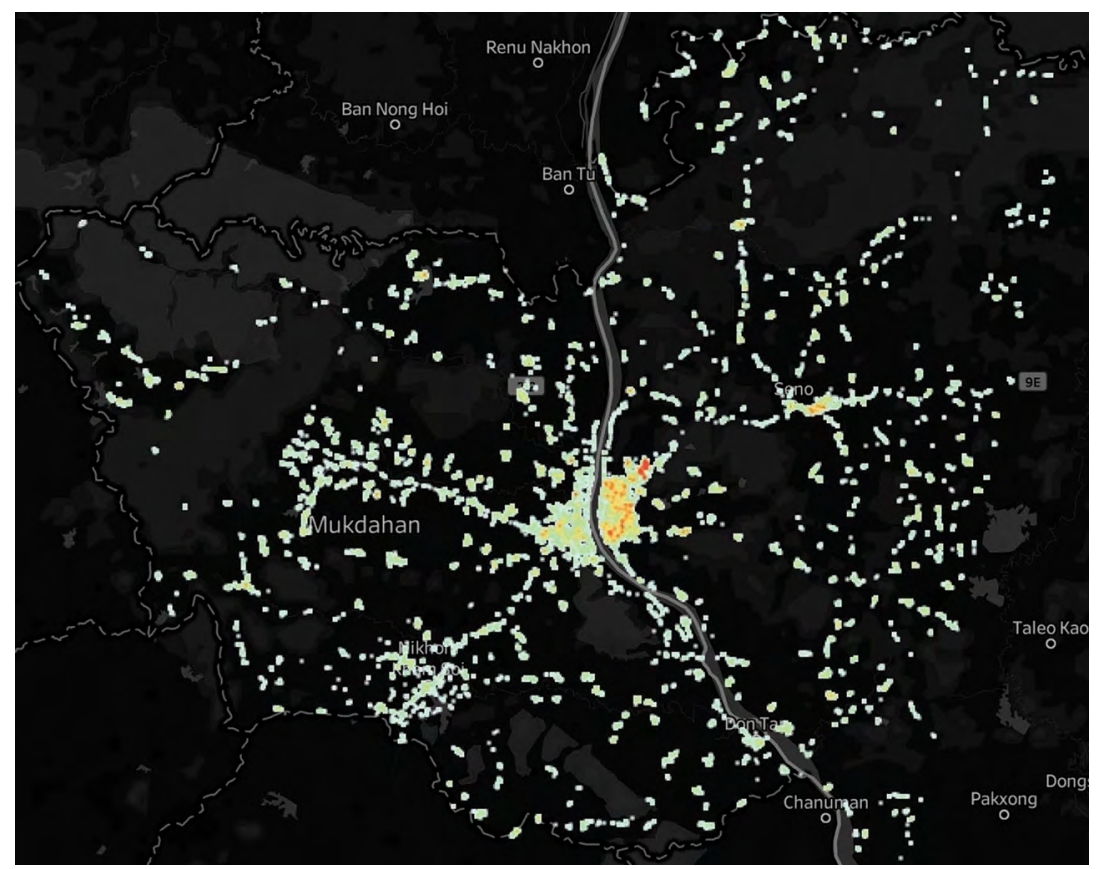

Figure 3.8d Location of newly created built-up areas in 2009 (second bridge)

Source: Authors' creation.

To quantify the observed growth pattern, we calculate the built-up area expansion within a radius of 0-10 kilometres and 11-30 kilometres north and south of the second friendship bridge. Figure 3.9 shows the radius analysis frame. Most of the existing city areas of Mukdahan and Savannakhet, as well as the Savan-Seno SEZ, lie within 10 kilometres south of the second bridge. The area in the 11-30-kilometre ring south of the bridge consists mainly of existing highways.

Figure 3.10 shows the annual increase in built-up area within various distances from the bridge between 2001 and 2018. One can see that most of the built-up area expansion occurred south of the bridge. Builtup areas in the 0-10-kilometre radius of Mukdahan and Savannakhet expanded rapidly from 2003 to 2004, which coincided with the opening of the Savan-Seno SEZ. After 2005, however, the expansion in this radius slowed while that in the 11-30-kilometre radius continued. The opening of the second friendship bridge in 2007 did not seem to alter the growth of built-up areas in any of the analysis frames. 


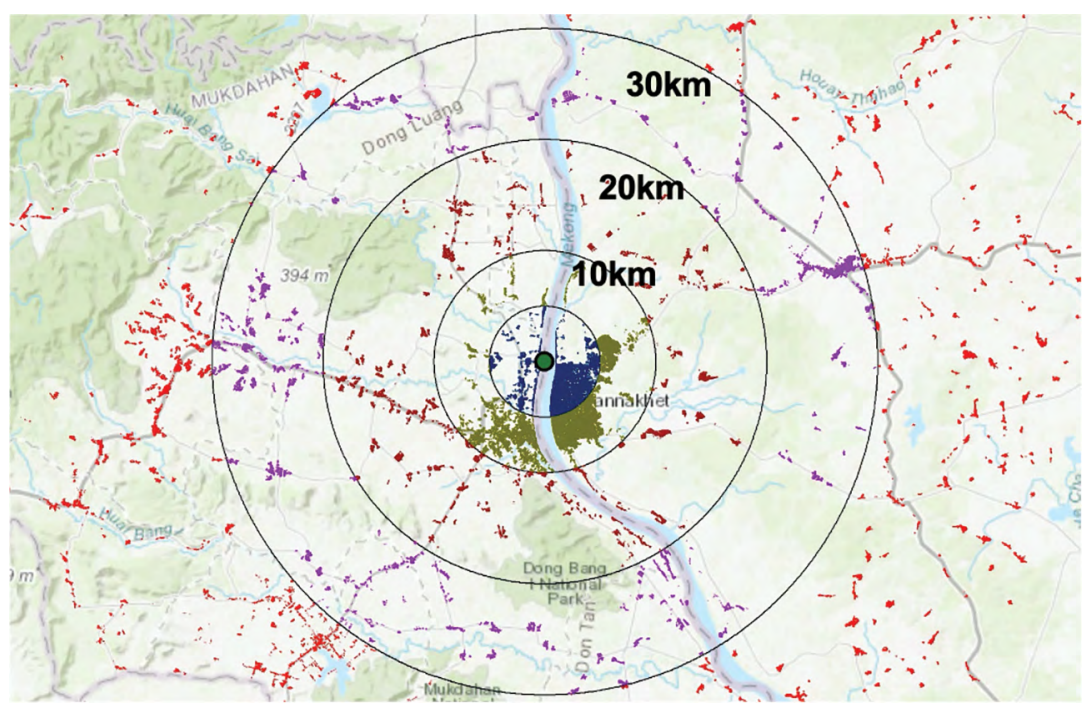

Figure 3.9 Radius analysis for Mukdahan and Savannakhet (second bridge)

Source: Built-up area map created using Landsat imagery from 2018.

Together, the analyses suggest that the creation of the Savan-Seno SEZ had a strong correlation with local urbanisation while the opening of the friendship bridges had no significant correlation with local urbanisation. Mukdahan appears to be just a throughway for the passage of goods and may benefit only from a small local spillover to communities along the highway leading up to the bridge. Therefore, we characterise the relationship for the second friendship bridge as industrialisation (from the SEZ) that rapidly drove connectivity (the bridge) and urbanisation.

We performed the same descriptive analysis for the third friendship bridge. Figure 3.11 plots the location of the new built-up hotspots in 2000, 2005, 2010 and 2015 in Nakhon Phanom and Khammouan. Built-up areas grew gradually out of the existing city cores and along major highways. The opening of the third friendship bridge in 2012 did not change the pattern of built-up area expansion in a profound way. 


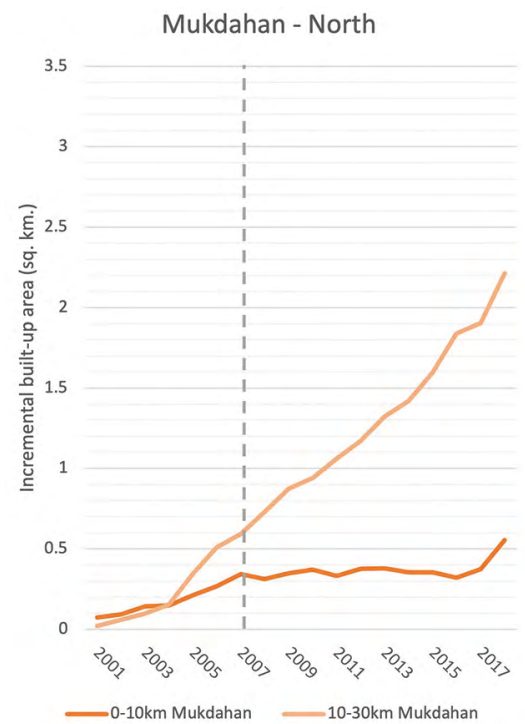

Mukdahan - South

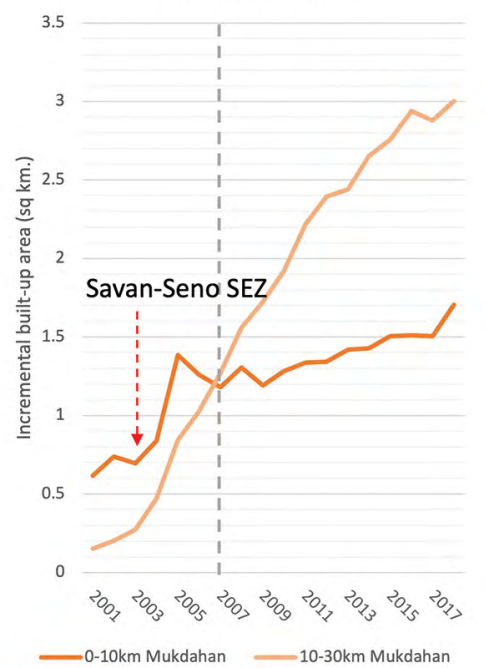

Savannakhet - North

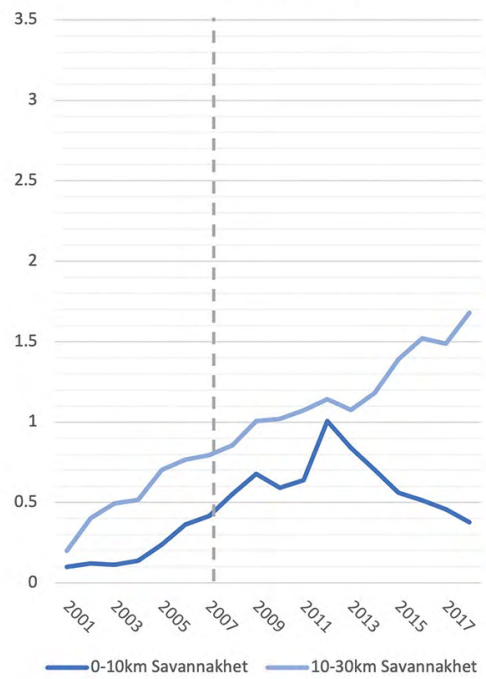

Savannakhet - South

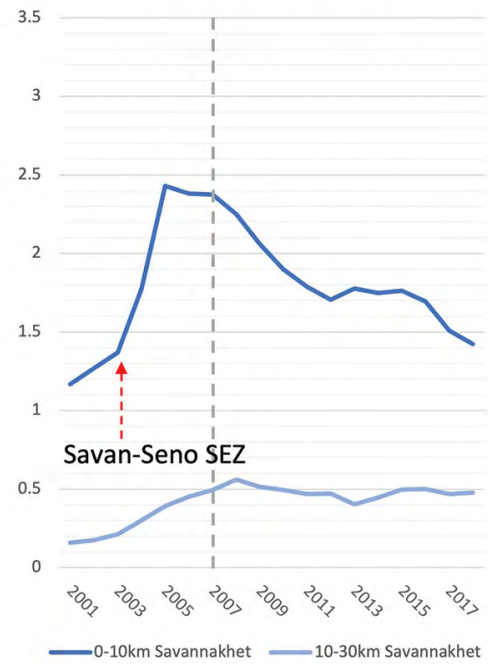

Figure 3.10 Annual increase in built-up area in Mukdahan and Savannakhet (second bridge)

Source: Authors' creation. 


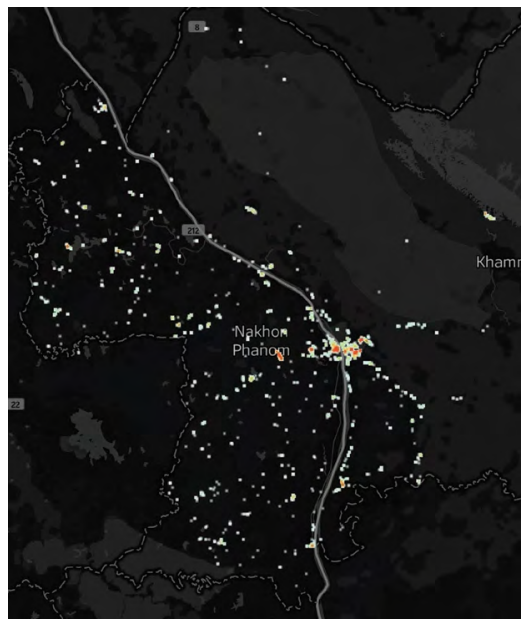

Figure 3.11a Location of new builtup areas in $\mathbf{2 0 0 0}$ (third bridge)

Source: Authors' creation.

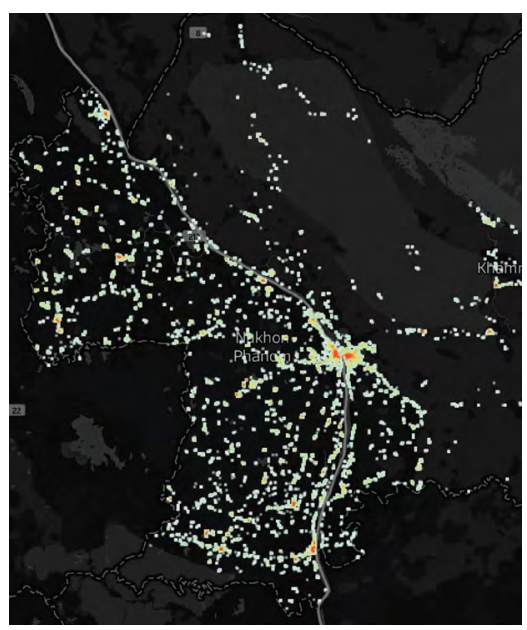

Figure 3.11b Location of new builtup areas in $\mathbf{2 0 0 5}$ (third bridge)

Source: Authors' creation.

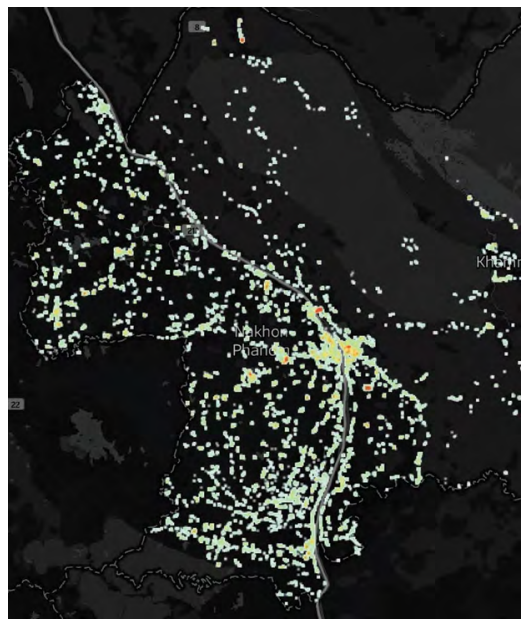

Figure 3.11c Location of new builtup areas in 2010 (third bridge)

Source: Authors' creation.

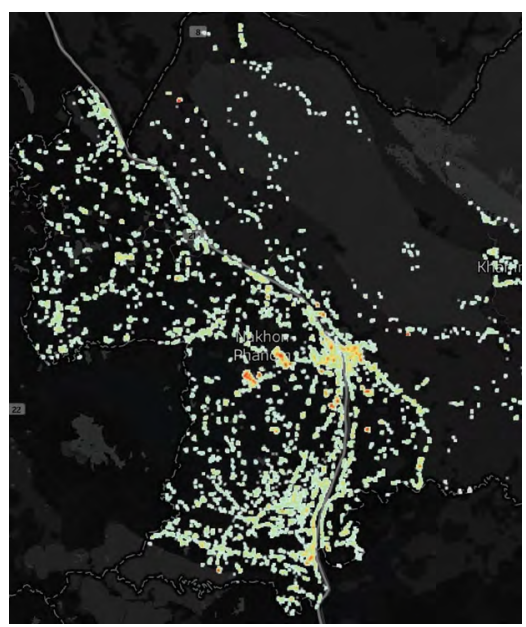

Figure 3.11d Location of new builtup areas in $\mathbf{2 0 1 5}$ (third bridge)

Source: Authors' creation. 


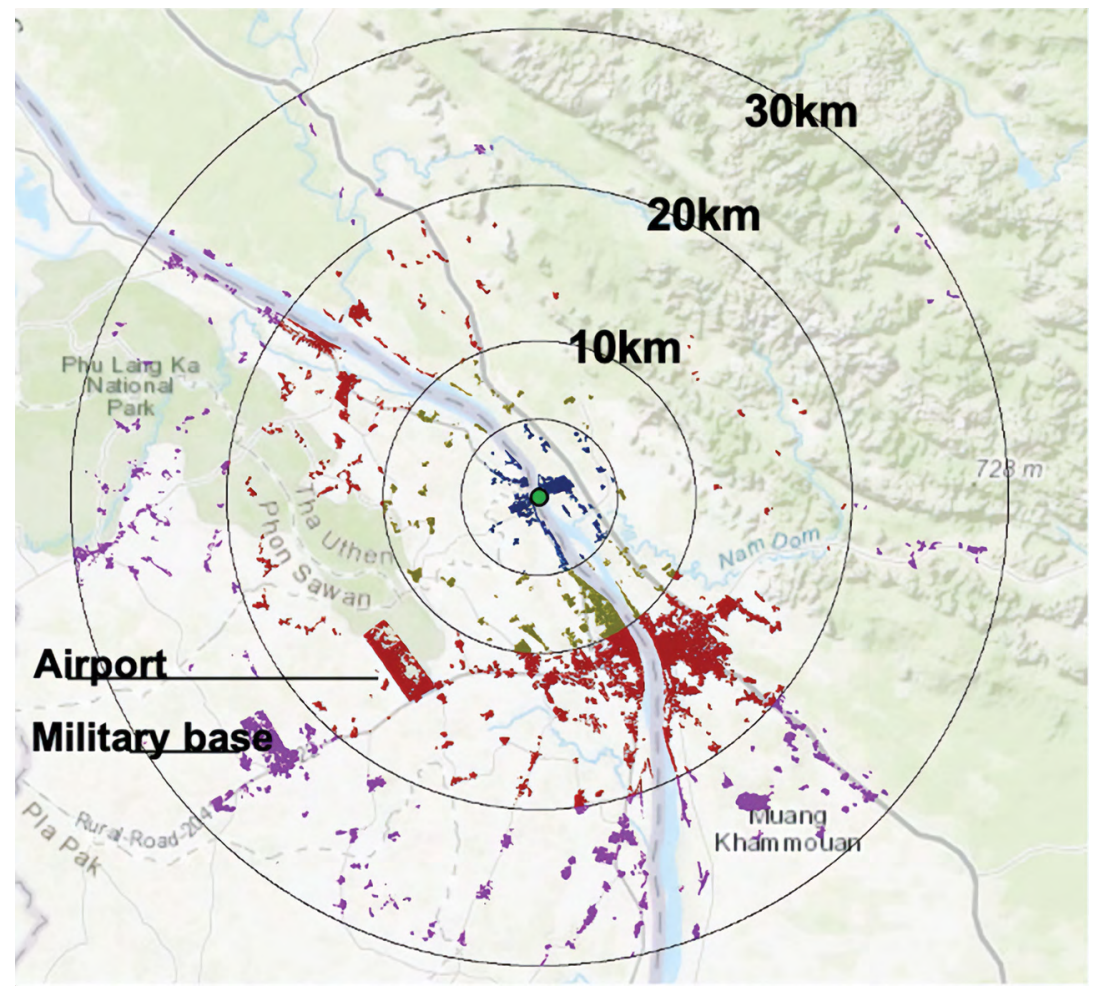

Figure 3.12 Radius analysis for Nakhon Phanom and Khammouan (third bridge)

Source: Map created using Landsat imagery for 2018.

A similar radius analysis for the third friendship bridge reveals that most of the existing city area (Nakhon Phanom and Khammouan) and major highways were located in the 10-30-kilometre ring south of the bridge (Figure 3.12). The newly created Thakhek SEZ in 2012 was in the same area.

Figure 3.13 plots the annual built-up area expansion in the $0-10$-kilometre and 11-30-kilometre radii north and south of the bridge. The plots reveal that most of the new built-up hotspots in both Nakhon Phanom and Khammouan are within the 11-30-kilometre ring south of the third friendship bridge. However, the trend in built-up area expansion does not show any significant change after the opening of the third bridge and the Thakhek SEZ in 2012. 
NEW DIMENSIONS OF CONNECTIVITY IN THE ASIA-PACIFIC
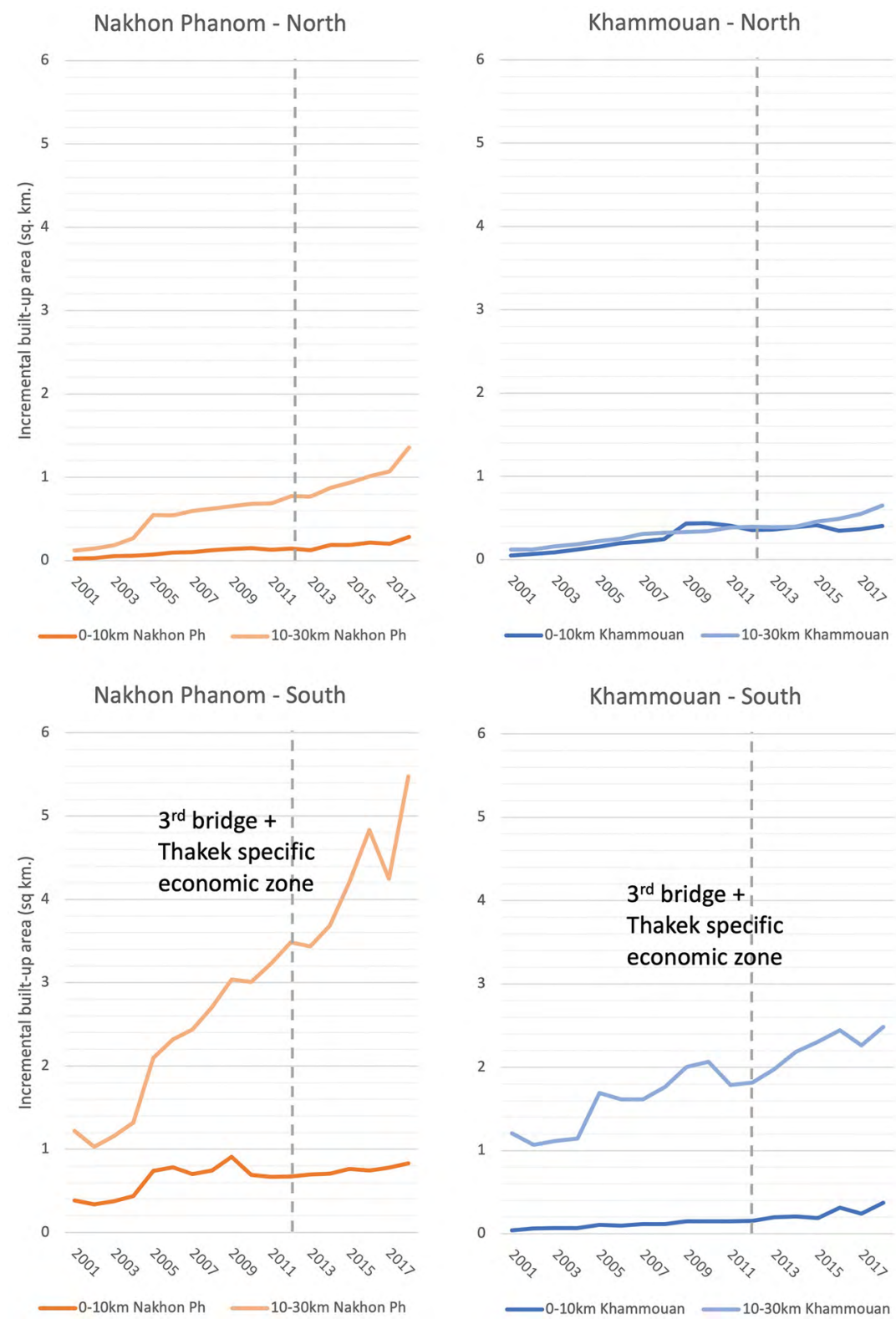

Figure 3.13 Annual increase in built-up area in Nakhon Phanom and Khammouan (third bridge)

Source: Authors' creation. 
Together, the data for the third friendship bridge indicate that new built-up areas continued to expand in relation to the existing cities and highways, not in relation to the bridge or the new Thakhek SEZ. Readers should be reminded that the context and timing of the third bridge and the SEZ are very different from those of the second bridge: the third bridge was built, first, to enhance connectivity in the region in general, and then the Thakhek SEZ in Laos was established to capture the spillover benefits from the bridge. Therefore, we characterise this relationship as connectivity (the bridge) slowly driving industrialisation and urbanisation.

Overall, our findings show that the friendship bridges, as connective infrastructure, contributed to a clear increase in economic activity-most notably, in cross-border trade and cross-border traffic. This is broadly in line with the findings of previous work on the economic benefits of transport infrastructure. We also find that the impacts of the two bridges on patterns of urbanisation in the connected cities largely depend on the historical context of the surrounding areas. This adds a new insight to previous findings that intercity transport infrastructure often produces uneven results in urbanisation between larger cities and smaller ones.

\section{Conclusions and policy implications}

Our major descriptive findings can be summarised as follows. First, connectivity has a strong direct relationship with border trade. This can be seen from the opening of the second and third Mekong friendship bridges, which were followed by an explosion in border trade value. Second, connectivity may not have a profound impact on local urbanisation since the built-up area surrounding the bridges continued to expand in relation to the existing cities, the SEZ and highways, but not in relation to the bridges. Last, the interaction between connectivity, industrialisation and urbanisation for the second bridge is characterised as industrialisation-driven urbanisation and connectivity. On the other hand, the interaction for the third bridge is characterised as connectivitydriven (slow) urbanisation and industrialisation.

Importantly, we would like to emphasise that the relationships we characterise here represent only the correlation between industrialisation, bridge construction and built-up area expansion. Estimating a causal relationship is not possible at the local level due to the lack of other control variables. Importantly, the observed increase in the built-up areas or trade 
volumes after the bridges' construction cannot be entirely attributed to the bridges as several other factors also influence growth. For example, existing highways and industrial policies (for example, the Savan-Seno SEZ) could have driven the growth in these border cities even without the bridges.

The main lesson learned from these two case studies is that enhanced physical connectivity alone may have significant direct benefits on trade; however, the indirect benefit spillovers on the local economy may be limited. Instead, careful industrial and urban planning, along with physical connectivity enhancement, have a much greater potential to create additional local benefits and maximise the returns on the investment in such large connective infrastructure.

Last, the current study presents several limitations that can serve as areas for future study. First, due to data limitations, the relationships we characterise here only capture the correlation (and not causation) between industrialisation, bridge construction and built-up area expansion. A future study that aims to estimate the causal impact of the SEZ or bridge construction should gather a richer and longer dataset to control for the confounding factors of urbanisation such as local policies or institutional detail on the bridge construction decision-making process. Second, the satellite imagery data and classification method used in this study lack the resolution and depth required to assess the quality of urbanisation. A future study can make use of the commercially available higher-resolution satellite data, additional ground-truth data and a more sophisticated classification technique to differentiate building types and the quality of urbanisation. Third, the lessons learned from the two case studies might not be representative of other connective bridges in the region. Different political, cultural and social contexts can result in different interactions between connectivity, industrialisation and urbanisation. Thus, expanding the study coverage to other countries in the GMS will result in generalisable policy implications.

\section{References}

Bank of Thailand. 2019. Value of exports and imports through Thai-Laos custom house in the north-east region. [Statistical Database.] Bangkok: Bank of Thailand. Available from: www.bot.or.th/App/BTWS_STAT/statistics/ReportPage.aspx? reportID $=549 \&$ language $=$ th . 
Baum-Snow, N., Brandt, L., Vernon Henderson, J., Turner M.A. and Zhang, Q. 2012. Roads, railroads and decentralization of Chinese cities. IGC Working Paper. London: International Growth Centre, London School of Economics and Political Science. Available from: www.theigc.org/wp-content/uploads/ 2014/09/Baum-Snow-Et-Al-2012-Working-Paper.pdf.

Celbis, M.G., Nijkamp, P. and Poot, J. 2013. How big is the impact of infrastructure on trade? Evidence from meta-analysis. MERIT Working Papers 2013-032. Maastricht, Netherlands: United Nations University-Maastricht Economic and Social Research Institute on Innovation and Technology. Available from: ideas.repec.org/p/unm/unumer/2013032.html.

De Riggi, J. 2017. 'Remote sensing series part 2: Landsat is the stalwart of satellite imagery platforms (and it's free!).' [Blog]. Digital @ DAI, 18 January. Available from: dai-global-digital.com/part-2-la-la-landsat-making-use-oflandsat-imagery.html.

Duranton, G. and Puga, D. 2004. 'Micro-foundations of urban agglomeration economies.' In J. Vernon Henderson and J.F. Thisse (eds), Handbook of Regional and Urban Economics. Amsterdam: Elsevier. doi.org/10.3386/w9931.

Earth Observing System Data Analytics (EOSDA). n.d. 'Landsat 5 (TM) bands.' Earth Observing System. Menlo Park, CA: EOSDA. Available from: eos.com/ landsat-5-tm.

Fernquest, J. 2011. 'Thai-Lao friendship bridges no.3 and 4.' Bangkok Post, 16 February. Available from: www.bangkokpost.com/learning/advanced/ 221957/thai-lao-friendship-bridges-no-3-and-4.

Fletcher, T. 2016. The Naked Diplomat: Understanding Power and Politics in the Digital Age. London: William Collins.

Fujimura, M. 2017. Evaluating impacts of cross-border transport infrastructure in the Greater Mekong Subregion: Three approaches. ADB Institute Working Paper No. 771. Tokyo: Asian Development Bank Institute. Available from: www.adb.org/sites/default/files/publication/352026/adbi-wp771.pdf.

Fujimura, M. and Edmonds, C. 2006. Impact of cross-border transport infrastructure on trade and investment in the GMS. ADB Institute Discussion Paper No. 48. Tokyo: Asian Development Bank Institute. Available from: citeseerx.ist.psu. edu/viewdoc/download?doi=10.1.1.468.6495\&rep=rep1 \&type=pdf.

GIS Resources. 2014. 'Why does NDVI, NDBI, NDWI ranges from -1 to 1 ?' [Online]. 13 April. Available from: www.gisresources.com/ndvi-ndbi-ndwiranges-1-1. 
Goldblatt, R., Deininger, K. and Hanson, G. 2018. 'Utilizing publicly available satellite data for urban research: Mapping built-up land cover and land use in Ho Chi Minh City, Vietnam.' Development Engineering 3: 83-99. doi.org/ 10.1016/j.deveng.2018.03.001.

Goldblatt, R., You, W., Hanson, G. and Khandelwal, A. 2016. 'Detecting the boundaries of urban areas in India: A dataset for pixel-based image classification in Google Earth Engine.' Remote Sensing 8(8): 634. doi.org/ $10.3390 / \mathrm{rs} 8080634$.

Ishida, M. 2013. Border Economies in the Greater Mekong Sub-Region. London: Palgrave Macmillan. Available from: doi.org/10.1057/9781137302915.

Ismail, N.W. and Mahyideen, J.M. 2015. The impact of infrastructure on trade and economic growth in selected economies in Asia. ADB Institute Working Paper No. 553. Tokyo: Asian Development Bank Institute. Available from: www.adb.org/sites/default/files/publication/177093/adbi-wp553.pdf.

Japan International Broadcasting Inc. (JIBTV). 2014. 'Bridging for trade.' JIBTV, 17 January. Available from: www.jibtv.com/programs/mekong-bridge2014.

Japan International Cooperation Agency (JICA). 2017. '10 years after JICA assisted the construction of 2 nd Thai-Lao Friendship Bridge, Japanese firms build factories, invigorating Laotian economy.' News, 31 July. Tokyo: JICA. Available from: www.jica.go.jp/english/news/field/2017/170731_01.html.

Ke, X., Chen, H., Hong, Y. and Hsiao, C. 2017. 'Do China's high-speed-rail projects promote local economy? New evidence from a panel data approach.' China Economic Review 44: 203-26. doi.org/10.1016/j.chieco.2017.02.008.

Li, Z. and Xu, H. 2018. 'High-speed railroads and economic geography: Evidence from Japan.' Journal of Regional Science 58(4): 705-27. doi.org/10.1111/ jors. 12384 .

Mukdahan Customs House. 2019. 'Passenger and vehicle traffic between Thailand and Laos border.' Annual Statistics of the Mukdahan Customs House for the fiscal year 2019. Mukdahan, Thailand: Mukdahan Customs House. Available from: www.danmuk.org/index.php?lay=show\&ac=article \&Id=2147552135.

Nakhon Phanom Immigration Office. 2012. Passenger and Vehicle Inspection Statistics. Nakhon Phanom, Thailand: Nakhon Phanom Immigration Office. Available from: www.nakhonphanom-imm.com/2012-08-10-06-57-28.

National Aeronautics and Space Administration (NASA). n.d. 'Data.' Landsat Science. [Online]. Houston, TX: NASA. Available from: landsat.gsfc.nasa. gov/data. 
National Centers for Environmental Information (NCEI). n.d. Version 4 DMSPOLS Nighttime Lights Time Series. Boulder, CO: NCEI. Available from: ngdc. noaa.gov/eog/dmsp/downloadV4composites.html.

Office of the National Economic and Social Development Council (NESDC). n.d. 'Province-level measure of value added.' Economic and Social Information. Bangkok: NESDC. Available from: www.nesdc.go.th/main. php?filename=gross_regional.

Oizumi, K. 2013. 'The potential of the "Thailand-plus-one" business model: A new fragmentation in East Asia.' Pacific Business and Industries 8(50).

Royal Thai Consulate-General. 2019. 'Laos opens a new special economic zone at Thakhek, Khammouane Province.' Press release, 13 June. Savannakhet, Laos: Royal Thai Consulate-General.

Thailand Ministry of Transport (MOT). 2008. Feasibility Study of the Third Mekong Bridge Construction Project (Nakhon Phanom). Bangkok: MOT.

United States Geological Survey (USGS). n.d. EarthExplorer. Reston, VA: USGS. Available from: earthexplorer.usgs.gov.

Vernon Henderson, J., Storeygard, A. and Weil, D.N. 2012. 'Measuring economic growth from outer space.' American Economic Review 102(2): 994-1028. doi.org/10.1257/aer.102.2.994.

Warr, P., Menon, J. and Yusuf, A. 2009. Regional economic impacts of cross-border infrastructure: A general equilibrium application to Thailand and Lao PDR. ADB Working Paper Series on Regional Economic Integration No. 35. Manila: Asian Development Bank. Available from: www.adb.org/sites/ default/files/publication/28509/wp35-crossborder-infrastructure.pdf.

World Bank. 2009. World Development Report 2009: Reshaping economic geography. Washington, DC: World Bank Group.

Yu, F., Lin, F., Tang, Y. and Zhong, C. 2019. 'High-speed railway to success? The effects of high-speed rail connection on regional economic development in China.' Journal of Regional Science 59(4): 723-42. doi.org/10.1111/ jors. 12420 . 
This text is taken from New Dimensions of Connectivity in the Asia-Pacific, edited by Christopher Findlay and Somkiat Tangkitvanich, published 2021 by ANU Press, The Australian National University, Canberra, Australia.

doi.org/10.22459/NDCAP.2021.03 